\title{
A New Frontier for Visual Culture
}

\author{
By David J. Prescott-Steed
}

Fall 2012 Issue of KINEMA

\section{A NEW FRONTIER FOR VISUAL CULTURE: THOUGHTS ON THE PRODUCTION AND CONSUMPTION OF DIGITAL DEEP-SEA IMAGERY}

The following discussion is a response to the proliferation of digital deep-sea imagery that has been emerging since the mid-1990s. Here, digital imagery is understood in William J. Mitchell's (1994, 7) postmodern social and cultural terms as "a medium that privileges fragmentation, indeterminacy, and heterogeneity and that emphasizes process or performance", and an "opportunity to expose the aporias of photography's construction of the visual world". A stock of visual documentation (still and moving images) is growing each day - widely available on the internet, in books (both for adults and for children), and in movie theatres internationally.

\section{Introduction}

Mindful of this new entertaining and educational material, it strikes me as problematic that there is a paucity of critical inquiry into the curatorial and signifying practices associated with its dissemination, certainly in terms of the broader implications for public awareness. Here, I draw attention to context for digital deep-sea imagery as a newly emergent research subject for the study of late modern visual culture.

Prototypical steps into the ocean's abysses mark a new phase in the relationship between humans and the sea - one with global significance but also particular relevance to Australian cultural heritage. Australia's long-standing relationship to the sea is as announced in our national anthem: "Our home is girt by sea". It is only once the representational conventions associated with deep-sea digital imagery are addressed that we may proceed to address the question how this new phase in deep-sea engagement will impact upon notions of Australian identity.

We can appreciate the practical importance of this awareness in the context of our nation's ongoing and active participation in global events such as deep-sea territorial claims. Supporting visual cultural research from the early stages of this new frontier, by contextualising Australia's negotiation of deep-sea imagery in relation to more global custodianship, is one way to help enrich Australian regional understanding. New technology and mediated experience is far-reaching, and our critical engagement should be equal in scope. There is clearly much ground to be uncovered pertaining to what may well prove to be one of the most transfixing and challenging frontiers of the next millennium.

\section{On the Rim of the Pit}

The world's abyssal zones comprise more than half of the globe's terrain, containing unique flora and fauna of which scientists have explored less than two percent. Deep-sea exploration is a frontier science for the twenty-first century, and draws on imagery previously unimagined in either scientific fields or qualitative analyses. It was in 2005 that Japanese scientists captured the first-ever photograph of a giant squid at play in its natural habitat (Owen 2005). Furthermore, in 2009, American scientists witnessed and recorded the eruption of a deep-sea volcano, named "NW Rota-1" (National Geographic 2009).

With deep-sea discoveries set to continue for centuries, human sea-activity already attracts significant attention in international political discussions. As science and industry venture deeper and deeper into the aquatic abyss, so too do extant environmental concerns find new depth and breadth. In this context, the question arises how we are to negotiate discourse on the education about, and demonstrate the protection of, flora and fauna. Additional difficulty comes from our not being entirely sure of what exists down there.

The deep-sea's commercial promise is now becoming clear, with financial investment in the deep-sea rivalling that reserved for outer space. Prior to the 2010 spill, British Petroleum's US $\$ 560$ million Deepwater Horizon oil rig in the Mexican Gulf had an ongoing running cost US $\$ 1$ million per day. Chevron's discovery of the Jack Field - the largest new discovery on land or seas in a decade - made world news in 2006 and gave US oil reserves a much needed boost (Mufson 2006). The United Nations responded directly to new economic interests by forming The Deep Sea Conservation Coalition, comprising over 60 organizations worldwide and 
concerned with the "conservation and protection of marine biodiversity in areas beyond national jurisdiction" (Gianni 2009).

Digital technology is mediating a new era in deep-sea awareness, making visible what cannot be seen by the naked eye (Mirzoeff 2009,5). Thus, as the textual nature of Western inventions of the deep-sea gives way to visual depictions, allowing new avenues for public education and entertainment in our ocular-centric society, there is cause to include digital deep sea imagery in the modern visual analysis debate. Overall, this means addressing the tensions of representation, the scientific image that modern visual technology reproduces, as well as the curatorial conventions and signifying practices through which this circumstance is articulated. This inclusion will further problematise the authority of scientific imagery internationally, though in a way that is particularly relevant to the Australian story as we move into the new millennium.

Of key interest is the production and dissemination of cultural representation and mediated meanings of the deep-sea. A long-term reliance on deep-sea images for an understanding of abyssal terrain and its features is almost certain to continue, given that few people will ever experience these regions at first-hand. The high cost of deep-sea exploration reserves such an experience for a privileged few. Thus, the public's deepsea awareness is subject to the scientists and digital media industries that have the privilege of capturing imagery to take back to the laboratory or to share with policy makers and consumers world-wide for a range of educational and entertainment purposes (Monterey Bay Aquarium Research Institute (MBARI); Nouvian 2007; Batson 2003, 2009; Cameron 1989, 2003, 2005; Low 2003).

The proliferation of deep-sea images and their public diffusion adds another to the existing spectacles of our culture. It is telling that three quarters of deep-sea documentaries ever made have been produced since 2000, many of which are purpose-made for IMAX (including Ghosts of the Abyss (2003), Aliens of the Deep (2005), Deep Sea (2006), and Under the Sea 3D (2009). Visual media and its technological advance play a vital role in understanding and exploring the new frontier. But the lack of scholarship addressing this phenomenon necessitates an examination of the representational and signifying practices by which the aquatic abyss is now naturalised as an object of mass spectatorship.

\section{Thinking through the Abyss}

The communicative power of digital imagery is a commonplace in social and visual analysis, from Walter Benjamin's Art in the Age of Mechanical Reproduction (1969) through to John Berger's Ways of Seeing (1972), Stuart Hall's Encoding/Decoding (1973) and Anthony Giddens' writings on mediated experience in Modernity and Self-Identity (1991). Gillian Rose's work in Visual Methodologies: An Introduction to the Interpretation of Visual Materials (2006) and Nicholas Mirzoeff's An Introduction to Visual Culture (2009) are among leading contemporary scholarship discussing representations of gender, ethnicity, sex, history and nature, but theoretical work is yet to directly address the deep-sea frontier. At a time of global attention to the ocean's natural endowments, its commercial, environmental and educational significance, the study of visual culture needs to be expanded to include scholarly focus on deep-sea imagery and its implications.

Discrepancy in the knowledge economies that inform policy decision making and popular perceptions is a familiar theme in Australian history, highlighting a desire to demonstrate mastery in the presence of the 'Other'. Australian colonial landscape painters, for example, were also faced with the challenges of interpreting the extreme and unfamiliar natural environment, which they depicted for audiences 'back home'. The idyllic was foremost, putting aside realistic representations in a kind of "souvenir hunting for a specific purpose" of capturing a place or exotic specimen "to paste it down firmly within the realm of the known and controllable" (Kerr 2009, 24). What Kerr refers to as the impetus to "prove one's triumphant survival across otherwise unbridgeable physical and cultural distances" is not limited to Australia's colonial past (Kerr 2009, $24)$.

There are grounds for the use of pictorial semiotics, with its cogence within art history and visual culture studies, in analysing deep-sea imagery as a means to advancing understanding of the representational paradigms and mediation processes by which deep-sea imagery is produced and communicated. This is intended to clarify the implications not only for policy but broader cultural practice as well. It means recognising deep-sea imagery as a new opportunity to draw from theories and methods suitable to elucidating the constructedness of assumptions, notions and narratives, as introduced by Barthes in Mythologies (1972[1957]) and 'Image Music Text' (1977). 
By examining the institutional contexts of image mediation (aquarium and museum exhibitions, film production, and book publication), it is possible to shed light on the broader sociological dimensions and implications of a remarkable scientific frontier, as the critical analysis of representations of gender, sexuality, race, and class have forged important pathways throughout the humanities and beyond. Cultural reflexivity must maintain a role in this process. As Sigurjón Hafsteinsson $(2009,291)$ says,

the interest in visual images conveyed by various disciplinary fields within the natural sciences, like deep sea exploration, is generally not depicted in its social or cultural context. Nor are visual images granted social agency that influences the formation of social relations. Rather, the interest seems to be limited to a mere passive, descriptive and objective or documentary view where the concept of the 'creator'...or 'the image' is not problematised.

The disinterested and objective scientific purview is understandable, though scientists participate in "embodied practices" influenced, as Hafsteinsson $(2009,299)$ states, by career trajectories, research competition, and the economic objectives of their employers and sponsors.

This circumstance compounds the truism that pictures are detached from what they represent, by further distancing the deep-sea from its audience. In the same way that the authority of church and state once preferred theological interpretations of the sea, in the late modern era, the technological capabilities afforded to deep-sea science and industry now hold custodianship of artefacts associated with this shared global frontier.

The Melbourne Museum - one such custodian - includes a deep-sea exhibit. Its dead and wrinkled abyssal fauna specimens account for a small percentage of the exhibit, and are shown alongside film footage and educational posters; in one of these the aquatic abyss is described as 'lonely'. What is the role of such detail in the educational experience? We can appreciate that this anthropomorphism reflects back upon how a viewer may interpret the dead specimens displayed behind Perspex; these are anatopisms that speak of curatorial challenges and human expectations behind the dissemination of deep-sea content, but remain subordinate to the spectacle.

To offer the reader some additional analysis of this exhibit, it is worth explaining that each dead fish specimen is matched to two elements placed beneath it: 1) a short piece of text explaining features or eating habits and; 2) a digital image showing a 'fresher' version of the specimen above (either freshly caught or 'in situ'). It is impossible to tell from the digital image or information provided that one of these, the Giant Hatchetfish, is barely the size of a human adult hand. The specimen compensates for the kind of photographic indeterminacy to which Mitchell refers (1994). Reading formal elements direct us to human decision making processes and, in turn, an enriched reading of the content via connecting it to the broader cultural context of human values. Although depicting conceivably alien creatures, the meaningful content of the exhibit is much closer to home than is suggested.

What is more, in an exhibit of predominantly digitalised material, comprising still and moving images, textual support plays a key role in steering interpretation. However, to the extent that it contains only descriptive detail, we may suggest that the information encourages uncritical awareness, despite the evident opportunities for subsequent independent and extra-exhibit inquiry. For example, below a cloudy image of an octopus, the text tells of how "Dr Tsunemi Kubodera of the National Science Museum in Tokyo took this first-ever live image of a giant squid in its natural environment". The viewer's reading of the digital image, while limited to descriptives, is not limited to the displayed representation of the natural world (which is in itself of rather poor quality). We can detect a hint at the broader realm of international scientific collaboration, implying an intercultural knowledge economy. As it stands, little detail pertaining to this broader context is included in the public display, impacting upon viewer exposure to the broader context of industrial culture's behaviour.

The intended focus is clear. An accompanying image, showing Dr Kubodera's forearm and hand, handling the remnant of a deep-sea squid's tentacle that was recovered with the camera (digital technology being the valuable party), privileges the human encounter as subject and objectifies the deep-sea remnant; the deep-sea is being acted upon and only acts in a death throe of nervous tissue. With the rest of the scientific body cropped out of a public gaze, the frame defers the work of reflexivity in favour of the immediacy of the 
spectacle of the documented power relationship being performed.

Another hint at cultural context is provided inside the entrance to this same exhibit, in the form of a board listing photographic attributions matching thumbnail images to organisations and individuals, including MBARI, the Commonwealth Scientific and Industrial Research Organisation (CSIRO), among various other institutions and authors. The small images of deep-sea flora and fauna become indexes of the play (recalling Mitchell's 'process or performance') of science and industry in the knowledge economy and it a point upon which to reiterate the value of exploring these cultural tendrils.

Whether or not this new subject matter is necessitating new curatorial practices remains to be addressed. Regardless, with our everyday experience of the deep-sea confined to mediation, critical and formalised approaches to achieving transparency in the broader international context of deep-sea custodianship and industry intervention are vital. With cultural institutions releasing mediated deep-sea imagery and content into the public sphere, each instance is an education opportunity pertaining to "the most common habitat on Earth" (Melbourne Museum 2011).

The construction of deep-sea meanings - a focus on the matter of contemporary myth-making - arises from the presence of deep-sea imagery in the public domain. Myth has been central in human responses to the sea throughout history, with the notion of primeval waters dating back to the birth of civilisation - Ancient Mesopotamia. Mills (2003) has addressed the legacy of sea-myth by discussing the psychology of terror in Odysseus and Poseidon as well as heroic confrontations with death in Gilgamesh. The West's ocean-fantasies heavily reference the Book of Genesis. The 'Black Sea-devil', 'Vampyroteuthis Infernalis' (literally: Vampire Squid from Hell), and the Hadal zone (6000 metres and below) each evoke notions of hell. Myth has greatly informed the abiding stereotypes in deep-sea representations.

Thinking about the deep-sea is not a new activity; what we now have are new technological circumstances under which to do so. Public perceptions of the ocean are not fixed, but instead respond to a material reality. Corbin (1994) addresses changing European sea-related discourses between 1750 and 1850, drawing from classical literature, travel literature, poetry, creative art, religion, science, and medicine. Corbin shows theological interpretations of the ocean in the late Middle Ages as fuelling fear of, and repulsion with, the ocean.

Deep-sea exploration and public awareness have long been affiliated with romantic and adventurous storytelling, e.g., Herman Melville's adventure novel, Moby Dick (1851) - a cornerstone of American romanticism. This, along with The Cruise of the Snark (London), epitomises the tradition of depicting "fragile man in his puny cockleshells of seacraft, [against] the vast, tempestuous sea exerting irresistible forces amidst a howling gale" (Wenk 1995, 3). Bradley (2010) reinforces the tradition of identifying the ocean as a muse for poetic literature, capable of evoking the terror and wonder of the sublime for a contemporary audience. Such traditional valorising sits uneasily with the new imagery and with the technologies that now seek to demystify the aquatic abyss.

Contemporary deep-sea technology marks new scope to reassess abiding deep-sea stereo-types, and includes the task of clarifying how curatorial and representational practices serve to naturalise assumptions about the value of the aquatic abyss for an industrialised culture. This concern bears relation to Steinberg's (2001, 8) attention to the "role of the ocean in the rise of modern world-system". He uses political geography and international relations to understand the sea against an industrial backdrop. However, we may advance this insight by taking into account, from the vantage point of deep-sea imagery production and consumption, international border wars and deep-sea territorial claims. Awareness of the sea's late-modern role is advanced in Broeze (1998), which addresses Australia's modern relationship to the sea. Advancing deep-sea awareness means making a contribution to the Australian story as we enter the new millennium.

Contemporary scholarship's perspective has been foreshortened. Kathryn Ferguson (2008) examines the representation of 'Otherness' in underwater documentaries; I examine deep-sea representations in the BBC documentary film The Abyss (2008a), with additional pilot work drawing attention to a new research pathway in visual culture $(2008 \mathrm{~b}, 2010)$. However, there remains much work to do in understanding the role of digital imagery in shaping public awareness of the abyssal zones.

Of key concern is the production, dissemination, and interpretation of deep-sea representations that are part 
of our more complex visual communication system. This discussion recognises that the impact of visual technologies on human awareness legitimises theory's use of pictorial semiotic method, which can now be used to address the signifying capacity of digital deep-sea images; to see if and how deep-sea images are engendered is one possibility, as is assessing how such images contribute to a fetishisation of this frontier. The discussion implies the author's intention to continue to build on this research idea in future work, by way of visually analysing disseminated artefacts, including deep-sea documentaries, museum exhibits, news media, and print publications - educational interfaces. The overarching aim is to foster understanding of the efficacies of the curatorial and representational practices that underpin sea-related myth-making in contemporary culture.

As a newly emergent research opportunity, the initial steps cannot be taken without an element of the experimental. However, the author understands that this work can be done through employing qualitative approaches, building upon the pictorial semiotic analysis by way of engaging directly in other ways, in the educational interfaces by which deep-sea knowledge is communicated to a public - both national and international. In practice, this means visiting Nausicaa (France), which was designated a Centre of Excellence by the UNESCO Intergovernmental Oceanographic Commission in 1999. In this instance, the visual analysis of exhibits is key, but there is certainly scope to speak with directors and possibly even technical staff, to gain understanding of its educational aims and why its outreach programs are so highly valued.

Discussions with directorial staff at MBARI, a key participant in global deep-sea research, would be strategic in generating cross-disciplinary awareness of the educational possibilities made available by their newly completed visual technologies centre. The MBARI continues with its educational plan, in part, through its EARTH initiative, using "near-real-time data from ocean observatories to design and test outreach with the Internet as an interface to scientists, teachers, students, and the public." Paying closer attention to such initiatives, ascertaining where these function within a broader taxonomy of global deep-sea intervention and representation, is a way to contextualise the production and dissemination of deep-sea digital imagery.

In-the-field engagement is designed to uncover the educational values of deep-sea representation. A humanities researcher, seeking to interrogate deep-sea meaning-making, potentially disrupts the common-place meanings and interpretations on offer. Thus, the method of analysis is also philosophical. The theoretical tools provided by the humanities to understand image genres, content and narrative can compliment social scientific methods for discussing context, effects, and strategic implementation of deep-sea images and associated artefacts. To advance our knowledge of deep-sea representations is to go beyond both representational tropes and curatorial norms by which our understanding of the sea is being mediated. Such research can contribute to Australia's cultural capital by illuminating the impact of international deep-sea intervention on Australian life.

\section{A Fitting Time to Foster Deep-sea Visual Cultural Research}

With deep-sea digital imagery showing terrain that has been hidden for millennia, a new research opportunity exists for which visual culture studies has long since been suitably equipped. As a researcher living in Australia, it is important to offer the reader a sense of the value that this topic holds for an Australian scholarly community. Doing so also gives the international reader a broader research context from which to further frame this discussion. This is why it is important to explain that this research into the production and consumption of deep-sea imagery speaks to Australia's National research priority - 'Safeguarding Australia: Understanding Our Region and the World'. Such research has the potential to provide cultural and social benefit to Australia by challenging and advancing our understanding of the impact of digital visual technologies on the Australian social imagination as we negotiate a new era of deep-sea awareness and response.

Furthermore, by addressing the custodianship, mediation and dissemination of deep-sea imagery, it is possible to glean insight into the border wars currently being fuelled by conflicting international claims to deep-sea resource exploration and extraction, habitat alteration and conservation. These and other pressing issues have severe economic and political implications as companies drill deeper and deeper for oil and minerals. China, Malaysia, Vietnam, and Taiwan are currently disputing territorial claims to the South China Sea in a highly volatile situation, for example. In particular, Australia's territorial claim to the Timor Sea-bed since the discovery of petroleum in the 1970s, overlaps East Timor's own claim. With audiovisual media 
providing a powerful means to raise consciousness of important social events and issues, the representation of deep-sea regions, such as maritime boundaries, is significant to the future of Australia's economic prospects and political relationships. Understanding how deep-sea awareness is mediated and constructed in view of developments will empower our society as we address the questions and challenges now brought to our doorstep by the abyssal zones of the new millennium.

\section{References}

\section{References}

Barthes, Roland. Mythologies. (Translated by Lavers, A.) France: Les Lettres Nouvelles 1972 [1957].

Barthes, Roland. Image Music Text. London: Fontana, 1977.

Batson, Peter. Deep New Zealand: Blue Water, Black Abyss. New Zealand: Canterbury University Press, 2003.

Batson, Peter. Into The Deep: Exploring The Earth's Oceans. London: Quercus, 2009

Benjamin, Walter. "The Work of Art in the Age of Mechanical Reproduction." In: H. Arendt (Ed.), Illuminations: Essays and Reflections. New York: Schocken Books 1969, pp. 217-252.

Berger, John. Ways of Seeing. London: Pelican, 1981.

Bradley, James. (Ed.) The Penguin Book of the Ocean. Hawthorn: Penguin. 2010.

Broeze, Frank. Island Nation: A History of Australians and the Sea. New South Wales: Allen \& Unwin, 1998.

Corbin, Alain. The Lure of the Sea: The Discovery of the Seaside in the Western World. Berkeley: University of California Press, 1994.

Cunningham, Stuart, and Graeme Turner. The Media and Communications in Australia. New South Wales: Allen \& Unwin, 2010.

Ferguson, Kathryn. "Submerged Realities: Shark Documentaries at Depth." In: V. Messier and N. Batra (Eds.), This Watery World: Humans and the Sea ( $2^{\text {nd }}$ ed.). United Kingdom; Cambridge Scholars Publishing, 2008, pp. 107-122.

Gianni, Mantero. "UNICP and the Conservation of Deep-sea Biodiversity in Areas Beyond National Jurisdiction: A Civil Society Perspective on the Effectiveness of the UNICP Process." United Nations Open-ended Informal Consultative Process on Oceans and the Law of the Sea Tenth meeting, 17-19 June 2009.

http://www.un.org/Depts/los/consultative_process/documents/10_M.Gianni.pdf. Accessed: 20 March 2011.

Giddens, Anthony. Modernity and Self-Identity: Self and Society in the Late Modern Age. California: Stanford University Press, 1991.

Hafsteinsson, Sigurjón B. "The Agency of Eternal Darkness: An Approach to Scientific Images of Deep Sea Exploration." Critical Arts 21:2, 2007.

http://dx.doi.org/10.1080/02560040701810065. Accessed 11 February 2011.

Hall, Stuart. "Encoding/Decoding." In: S. Hall, D. Hobson, A. Lowe and P. Willis (Eds.), Culture, Media, Language: Working Papers in Cultural Studies, 1972-79. London: Routledge 1991 [1973], pp. 107-116.

Hogan, D. and Hogan, M. (Eds.) "Erupting Undersea Volcano Near Island Of Guam Supports Unique Ecosystem." Science Daily online.

http://www.sciencedaily.com/releases/2009/05/090505111702.htm. Accessed 5 May 2009. 
Kerr, Joan. "Views, Visages, Invisibility: Themes in the Art of Colonial New South Wales." In: C. Bruce, D. Dysart and J. Holder (Eds.). A Singular Voice: Essays on Australian Art and Architecture. Sydney: Power Publications, pp.22-35, 2009.

London, Jack. The Cruise of the Snark. New York: Macmillan, 1911.

Melville, Herman. Moby Dick New York: Harper \& Brothers Publishers, 1851.

Mills, Donald H. The Hero and the Sea: Patterns of Chaos in Ancient Myth. Illinois: Bolchazy-Carducci Publishers, 2003.

Mirzoeff, Nicholas. An Introduction to Visual Culture (2nd ed). London: Routledge, 2009.

Mitchell, William J. The Reconfigured Eye: Visual Truth in the Post-photographic Era. Massachusetts: Massachusetts Institute of Technology Press, 1994.

Monterey Bay Aquarium Research Institute. 2011 What is EARTH?

http://www.mbari.org/earth/. Accessed 23 January 2012.

Mufson, Steven. "U. S. Oil Reserves Get a Big Boost." The Washington Post, 2006.

http://www.washingtonpost.com/wpdyn/content/article/2006/09/05/AR2006090500275.html. Accessed 10 March 2011.

National Geographic Society. "Deep Eruption, Odd Shrimp Seen." National Geographic 2011.

http://video.nationalgeographic.com/video/player/news/environment-news/guam-underseavolcanovin.html. Accessed 11 February 2011.

Nouvian, Claire. The Deep: The Extraordinary Creatures of the Abyss. Chicago: University of Chicago Press, 2007.

Owen, James. "Holy Squid! Photos Offer First Glimpse of Live Deep-Sea Giant." National Geographic News. 27 Sept. 2005.

http://news.nationalgeographic.com/news/2005/09/0927/050927_giant_squid.html. Accessed 28 April 2011.

Prescott-Steed, David. 2008a "Contemporary Mass Media Representation of the Abyssal Zone." In: V. Messier and N. Batra (Eds.), This Watery World: Humans and the Sea (2 ${ }^{\text {nd }}$ ed). United Kingdom; Cambridge Scholars Publishing, pp. 31-48.

Prescott-Steed, David. 2008b "Surface and Depth: (Inter)facing the Abyssal Zone." Octopus: A Visual Studies Journal 4: 73-87.

Prescott-Steed, David. 2010 "Nemo's Abyss: The Deferral of Undecidability. Philament." Online Journal of the Arts and Culture 16: 34-49.

http://sydney.edu.au/arts/publications/philament/issue16_pdfs/PRESCOTT-STEED.pdf. Accessed 10 April 2011.

Rose, Gillian. Visual Methodologies: An Introduction to the Interpretation of Visual Materials (2 ${ }^{\text {nd }}$ ed). London: Sage., 2006.

Steinberg, Philip E. "The Social Construction of the Ocean" (Cambridge Studies in International Relations). Cambridge: Cambridge University Press, 2001.

Wenk, Edward Jr. Making waves: Engineering, politics and the social management of technology. Urbana: Illinois University Press 1995.

\section{Films}

Cameron, J. Ghosts of the Abyss. Walt Disney Pictures 2003.

Cameron J. Aliens of the Deep. Walt Disney Pictures, 2005. 
Hall, H. Deep Sea. Canada: IMAX 2006.

Hall, H. Under the Sea 3D. Canada: IMAX. 2009.

Low, S. Volcanoes of the Deep Sea. California: Egami, 2003.

\section{Author Information}

David John PRESCOTT-STEED PhD is an artist, writer and urban explorer living in Melbourne, Australia. He currently teaches art history and contemporary visual culture at the Australian Academy of Design (Melbourne). His writings include book chapters and articles published in Australia, France, Canada, the UK, the US, and Sweden. 